\title{
Profound Growth Failure in Peripubertal Adolescents presenting with Severe Acquired Autoimmune Hypothyroidism
}

\author{
Sze May $\mathbf{N g}^{\star}$ and Louise J Apperley \\ Department of Paediatrics, Southport and Ormskirk NHS Trust, Ormskirk, United Kingdom
}

\section{Article Info

*Corresponding author:
Sze May Ng
Department of Paediatrics
Southport and Ormskirk NHS Trust
Ormskirk, United Kingdom
Tel: 01695656163
Fax: 01695656282
E-mail: may.ng@nhs.net

Received: May 29, 2019

Accepted: June 20, 2019

Published: June 27, 2019

Citation: Ng SM, Apperley LJ. Profound Growth Failure in Peripubertal Adolescents presenting with Severe Acquired Autoimmune Hypothyroidism. Int J Pediatr Neonatal Prim Care. 2019; 1(1): 24-27.

doi: 10.18689/ijpn-1000107

Copyright: (c) 2019 The Author(s). This work is licensed under a Creative Commons Attribution 4.0 International License, which permits unrestricted use, distribution, and reproduction in any medium, provided the original work is properly cited.

Published by Madridge Publishers

\begin{abstract}
Introduction: Optimal thyroid function levels are essential for neurodevelopment, growth and pubertal development. Hypothyroidism is the most common endocrine disorder and is caused by an underactive thyroid gland.
\end{abstract}

Methods: Four peri-pubertal females were referred to a local paediatric centre with profound short stature. All patients were diagnosed with autoimmune hypothyroidism. This case series reports on the presentation, investigations and management of females with severe autoimmune hypothyroidism and presented with short stature.

Results: All four females were peri-pubertal on presentation to clinic and were found to have poor growth and significant short stature at -3.16 to -4.99 SD. Biochemical results confirmed severe hypothyroidism ( $\mathrm{TSH}>100$ and $\mathrm{FT} 4<1$ ) with positive thyroid peroxidase antibodies for all patients. All four patients had normal growth hormone stimulation tests and significantly delayed bone age [mean 3.3 years]. All patients had a thyroid ultrasound, which confirmed thyroiditis. Height SDS improved following thyroid replacement by $0.645 \pm 0.515 S D$.

Conclusion: It is important to consider hypothyroidism as a cause for poor growth in children and prompt recognition is essential to initiate treatment early, so that adult height is not compromised.

Keywords: Autoimmune; Hypothyroidism; Thyroiditis; Short Stature.

Abbreviations: Pubertal Staging B: Breast Stage; Pubertal Staging P: Pubic Hair Stage; Pubertal Staging A: Axillary Hair Stage; Pubertal Staging M: Menarche Stage; SDS: Standard Deviation Scores; TPO: Thyroid Peroxidase; TSH: Thyroid Stimulating Hormone.

\section{Introduction}

Hypothyroidism is the most common endocrine disorder, which is a result of an underactive thyroid gland $[1,2]$. Most cases are diagnosed by high levels of thyroid stimulating hormone (TSH) and low levels of free T4(FT4) [1,2]. Euthyroid, normal thyroid hormone levels, is essential for optimal neurodevelopment, growth and pubertal development $[3,4]$. Thyroid hormones are involved in the growth hormone process, especially the production and triggering of insulin-like growth factor 1 [4].

Autoimmune hypothyroidism is the most common type of hypothyroidism in Western Countries. It is mostly characterised by the presence of thyroid autoantibodies [1-3]. The clinical picture of the disorder can vary between individuals. 
Autoimmune thyroiditis often occurs during adolescence period, between early and mid-puberty. The condition is predominantly seen in females $[2,3,5]$ with a prevalence of $1-2 \%$ [6]. In 1995, Vander pump reported the incidence for autoimmune hypothyroidism as 0.6 and 4.1 per 1000 in males and females retrospectively [7]. These numbers have barely changed over the years as Halawani et al. showed in a systematic review in 2017 that the incidence was 0.8 and 3.5 per 1000 in males and females retrospectively [8].

There are multiple signs and symptoms for hypothyroidism which include lethargy, increased weight, intolerance to cold, constipation and lanugo-like hair $[1,3,6]$. The presence of goitre usually triggers the patient to seek medical advice and is found to be the most common presentation [2]. Interestingly, one of the most common clinical findings in patients diagnosed with hypothyroidism is slowing growth velocity $[2,3,9]$. It is a gradual progression and may have been ongoing for years before diagnosis is made [2]. Other associations with hypothyroidism are bone delay and pubertal concerns $[3,6,9]$.

The treatment for hypothyroidism is levothyroxine $[1,6]$. The thyroid function tests must be monitored closely initially until optimal thyroxine replacement has been achieved. The overall aim for treatment is to maintain a euthyroid picture, both clinically and biochemically [6].

In delayed treatment of hypothyroidism during peripubertal growth, even with optimal treatment, studies have reported that catch up growth may not be possible. This is thought to be secondary to skeletal progression following the initiation of thyroxine and, if the treatment is delayed and therefore the child is older, this allows less time for catch up growth to occur [10,11].

The aim of this paper was to evaluate the presentation, investigations and catch up growth following thyroxine treatment.

\section{Method}

Fourperi-pubertal females presented to a local paediatric centre between September 2014 and December 2018 with severe growth restriction and later diagnosed with autoimmune hypothyroidism. All patients had been seen by their general practitioners prior to being referred to the paediatric endocrinologist for short stature.

Pubertal status was staged according to Odel W [12]. Height and body mass index was expressed as standard deviation scores (SDS) with reference to British standards [13] and bone age was estimated by a consultant radiologist in the Department of Radiology using the RUS (TW2) [14].

Each patient had their TSH, FT4 and Thyroid peroxidase antibodies (TPO) assessed along with growth hormone stimulation tests using glucagon stimulation test as per local protocol. Their thyroid function was then monitored following the initiation of thyroxine replacement. All patients also had wrist $\mathrm{X}$-rays, to determine their bone age, and thyroid scans. The growth of the patients was monitored and plotted onto appropriate growth charts every three to four months.

\section{Results}

The main symptom for referral for all patients was short stature. Following a full history and examination, further symptoms were noted such as constipation, cold intolerance and low mood. None of the patients had physical signs of hypothyroidism, for example bradycardia, goitre, pretibial oedema or delay in relaxation of the ankle reflex.

All four patients had TSH levels over $100 \mathrm{mU} / \mathrm{L}$ at presentation with undetectable FT4 levels. The positive TPO antibodies along with ultrasound findings of thyroiditis support the diagnosis of autoimmune hypothyroidism. The hormone stimulation tests were normal, which show that the short stature is secondary to hypothyroidism and not a growth hormone problem. Bone age delay was also noted in all four patients, with a mean delay of 3.3 years (Tables 1 and 2). Coeliac screen, insulin-like growth factor 1 and karyotype were also all normal in these patients.

Table 1. Demographic, symptoms and examination findings at presentation.

\begin{tabular}{|c|c|c|c|c|c|c|}
\hline Patient & $\begin{array}{c}\text { Age at presentation } \mathrm{F} \\
(\mathrm{yrs})\end{array}$ & Presenting Symptoms & $\begin{array}{l}\text { Pubertal Staging } \\
\text { at presentation }\end{array}$ & $\begin{array}{c}\text { Weight SDS at } \\
\text { presentation }\end{array}$ & $\begin{array}{c}\text { Height SDS at } \\
\text { presentation }\end{array}$ & $\begin{array}{c}\text { Mid-parental } \\
\text { height }(\mathrm{cm})\end{array}$ \\
\hline 1 & 15 & One year history of constipation and short stature & В3Р3А2M1 & -3.22 & -4.99 & 160 \\
\hline 2 & 13 & $\begin{array}{l}\text { One year history of constipation, low mood, cold intolerance and } \\
\text { poor growth }\end{array}$ & В3Р3А2M1 & -0.61 & -3.23 & 168 \\
\hline 3 & 14 & $\begin{array}{l}\text { Patient had a dizzy spell and collapse at school. A more detailed } \\
\text { history revealed she had suffered from cold intolerance, dry skin } \\
\text { and hair for the last two years. }\end{array}$ & B2P2A1M0 & -1.93 & -4.35 & 157 \\
\hline 4 & 13 & Short stature & B4P4A2M1 & -0.19 & -3.16 & 168 \\
\hline
\end{tabular}

SDS: Standard Deviation Score

Table 2. Investigations for each patient.

\begin{tabular}{|c|c|c|c|c|c|c|}
\hline Patient & $\begin{array}{c}\text { TSH at Presentation } \\
(\mathrm{mU} / \mathrm{L})\end{array}$ & $\begin{array}{c}\text { FT4 at Presentation } \\
(\mathrm{pmol} / \mathrm{L})\end{array}$ & TPO Antibodies & $\begin{array}{c}\text { Growth Hormone Stimulation Tests } \\
\text { using Glucagon }\end{array}$ & $\begin{array}{c}\text { Bone Age Delay } \\
\text { (years) }\end{array}$ & \begin{tabular}{c} 
Thyroid Ultrasound \\
\hline 1
\end{tabular} \\
\hline 100 & Undetectable & Positive & Normal & 5 & Thyroiditis \\
\hline 2 & $>100$ & Undetectable & Positive & Normal & 2 & Thyroiditis \\
\hline 3 & $>100$ & Undetectable & Positive & Normal & 3.8 & Thyroiditis \\
\hline 4 & $>100$ & Undetectable & Positive & Normal & 2.5 & Thyroiditis \\
\hline
\end{tabular}

Table 3 shows that the thyroid function tests were normalising in all patients after eight weeks of treatment with thyroxine. The normal range for TSH is 0.4 to $4.0 \mathrm{mU} / \mathrm{L}$ and for

FT4 it is9 to $25 \mathrm{pmol} / \mathrm{L}$. The results also show that following thyroxine treatment the patients height SDS improved by $0.645 \pm 0.515$ (Table 4). 
Table 3. Change in thyroid function tests following the initiation of thyroxine treatment. TSH is measured in $\mathrm{mU} / \mathrm{L}$ and $\mathrm{T} 4 \mathrm{in} \mathrm{pmol} / \mathrm{L}$.

\begin{tabular}{|c|l|c|c|}
\hline Patient & Baseline & 4 weeks after Thyroxine & 8 weeks after Thyroxine \\
\hline \multirow{2}{*}{1} & TSH $>100$ & TSH-47.25 & TSH-0.56 \\
& T4 $<1$ & T4-10.9 & T4-20.6 \\
\hline \multirow{2}{*}{2} & TSH $>100$ & TSH-3.32 & TSH-0.6 \\
& T4 $<1$ & T4-10.9 & T4-15.4 \\
\hline \multirow{2}{*}{3} & TSH $>100$ & TSH-3.32 & TSH-0.17 \\
& T4 $<1$ & T4-22.7 & T4-22.9 \\
\hline \multirow{2}{*}{4} & TSH $>100$ & TSH-15.1 & TSH-10.74 \\
& T4 $<1$ & T4-9.44 & T4-12.4 \\
\hline
\end{tabular}

Table 4. Height SDS at presentation and following thyroxine treatment.

\begin{tabular}{|l|c|c|}
\hline Patient & $\begin{array}{c}\text { Height SDS at } \\
\text { Presentation }\end{array}$ & $\begin{array}{c}\text { Height SDS following 4-6 months of } \\
\text { Thyroxine }\end{array}$ \\
\hline Patient 1 & -4.99 & -3.83 \\
\hline Patient 2 & -3.23 & -2.69 \\
\hline Patient 3 & -4.35 & -3.43 \\
\hline Patient 4 & -3.16 & -3.03 \\
\hline
\end{tabular}

\section{Discussion}

Our findings showed that for each patient the hormone stimulation responses were normal and therefore the short stature at presentation was secondary to severe hypothyroidism. This shows the importance of investigating the thyroid function when referred a patient with short stature or reduced height velocity. Other investigations for possible autoimmune hypothyroidism should also include thyroglobulin and thyroid peroxidase antibodies to aid diagnosis. They are thought to be positive in $50 \%$ and $90 \%$ of patients, respectively [2]. $5 \%$ of patients have a negative antibody screen, but diagnosed due to clinical signs or findings on their thyroid ultrasound [2].

Eskes et al. investigated growth hormone deficiency in patients with autoimmune hypothyroidism as it was thought that it was more common than initially thought secondary to autoimmune hypophysitis [15]. This would therefore change medical management for the patients. De Bellis et al. and Manetti et al. both found an association between autoimmune hypothyroidism and growth hormone deficiency [16,17]. Interestingly, Eskes et al.'s study did not show this association and their conclusion was that growth hormone investigations were not indicated [15]. Even though our cohort of patients agreed with this theory, it is reassuring that the growth hormone stimulation tests were normal and no other treatment was required.

It has also been reported that by adding a gonadotropinreleasing hormone $(\mathrm{GnRH})$ analogue to thyroxine treatment, that final height may be improved although results were not conclusive. Teng et al. reviewed thirty three children retrospectively comparing the final height and body mass index in children treated with thyroxine only and those who were treated with both medications [18]. The group of children treated with $\mathrm{GnRH}$ analogues were older and shorter than the other group at presentation and the final results showed that both groups had comparable final heights and height deficits [18].

Growth is important for a child's quality of life and can cause significant anxiety for all those involved [4]. Therefore, optimising catch-up growth is essential for their well-being. There are some reported concerns that final adult height may be reduced following thyroxine treatment due to the sudden increase in bone age progression [10]. Nebesio et al. investigated whether the time to reach euthyroidism was associated with final height outcome and found no significant difference [10]. The authors found no association with additional growth promoting treatments [10]. Our results have shown that following the introduction of thyroxine treatment alone, the height SDS for each peri-pubertal patient improved significantly. Jaruratanasirikul et al. followed up patients with Hashimoto's thyroiditis for six years [19]. The group of patients aged between 9-15.4 years old with biochemical hypothyroidism were found to have normal growth and puberty [19]. Interestingly, the final heights were on average above the mid-parental height [19]. In contrary, an older study showed that hypothyroidism diagnosed in the adolescent period resulted in a reduction in final adult height and was also associated with the delay in diagnosis [20]. These results demonstrate the importance of early detection of hypothyroidism so that treatment can be commenced as a priority.

The stage of puberty has been suggested to affect catchup growth. de Vries et al. followed up their patients for a total of six years and found that the height SDS improved significantly [11]. This was shown in their entire group, including pubertal patients [11]. This theory was also supported by Jaruratanasirikul et al. [19].

In this cohort, our patients have shown improvements in height following immediate treatment. It is important to investigate appropriately, and to include thyroid function tests in patients presenting with growth deceleration and short stature [2].

\section{Conclusion}

In conclusion, prompt recognition of hypothyroidism in childhood is essential to initiate treatment early, so that adult height is not compromised.

\section{Acknowledgement}

None

\section{Statement of Ethics}

Consent obtained from all patients and data was anonymised.

\section{Disclosure Statement}

No conflicts of interest to disclose.

\section{Funding}

\author{
None
}




\section{Author Contributions}

LA - analysed the data, wrote and revised draft.

SMN - supervised the audit, collected data and revised the final draft.

\section{References}

1. Chakera AJ, Pearce SH, Vaidya B. https://www.ncbi.nlm.nih.gov/ pubmed/22291465. Drug Des Devel Ther. 2012; 6: 1-11. doi: 10.2147/ DDDT.S12894

2. Schumaker T, Censani M. Growth Failure and Excessive Weight Gain in a 10 Year Old Male with Obesity: Approach to Diagnosis, Management, and Treatment of Acquired Hypothyroidism. Front Pediatr. 2018; 6: 166. doi: 10.3389/fped.2018.00166

3. Cappa M, Bizzarri C, Crea F. Autoimmune thyroid diseases in children. J Thyroid Res. 2011; 2011: 675703. doi: 10.4061/2011/675703

4. Saranac L, Stamenkovic H, Stankovic T, Markovic I, Zivanovic S, Djuric Z. Growth in Children with Thyroid Dysfunction. In: Potluková E (ed). Current Topics in Hypothyroidism with Focus on Development: InTech; 2013. doi: $10.5772 / 55017$

5. Demirbilek H, Kandemir N, Gonc EN, Ozon A, Alikasifoglu A, Yordam N. Hashimoto's thyroiditis in children and adolescents: a retrospective study on clinical, epidemiological and laboratory properties of the disease. $J$ Pediatr Endocrinol Metab. 2007; 20(11): 1199-1205.

6. Hanley P, Lord K, Bauer AJ. Thyroid Disorders in Children and Adolescents: A Review. JAMA Pediatr. 2016; 170(10): 1008-1019. doi: 10.1001/ jamapediatrics.2016.0486.

7. Vanderpump MP, Tunbridge WM, French $J M$, et al. The incidence of thyroid disorders in the community: a twenty-year follow-up of the Whickham Survey. Clin Endocrinol (Oxf). 1995; 43(1): 55-68.

8. Halawani HM, Ali Naji AN, M Alahmari MS, et al. A Literature Review on the Incidence of Autoimmune Thyroid Diseases. EC Endocrinology and Metabolic Research. 2017; 1(1): 10-18

9. Gyon $\mathrm{YH}, \mathrm{Han} \mathrm{HS}$. Massive pericardial effusion and short stature caused by autoimmune hypothyroidism in a 9-year-old girl. Ann Pediatr Endocrinol Metab. 2015; 20(2): 98-101. doi: 10.6065/apem.2015.20.2.98
10. Nebesio TD, Wise MD, Perkins SM, Eugster EA. Does clinical management impact height potential in children with severe acquired hypothyroidism? J Pediatr Endocrinol Metab. 2011; 24(11-12): 893-896.

11. de Vries L, Bulvik S, Phillip M. Chronic autoimmune thyroiditis in children and adolescents: at presentation and during long-term follow-up. Arch Dis Child. 2009; 94(1): 33-37. doi: 10.1136/adc.2007.134841

12. Odel W. Puberty. In: DeGroot L (ed). Endocrinology. Philadelphia: Saunders; 1989.

13. Freeman JV, Cole TJ, Chinn S, Jones PR, White EM, Preece MA. Cross sectional stature and weight reference curves for the UK, 1990. Arch Dis Child. 1995; 73(1): 17-24. doi: 10.1136/adc.73.1.17

14. Tanner JM, Whitehouse RH, Marshall WA, Carter BS. Prediction of adult height from height, bone age, and occurrence of menarche, at ages 4 to 16 with allowance for midparent height. Arch Dis Child. 1975; 50(1): 14-26. doi: 10.1136/adc.50.1.14

15. Eskes S, Endert E, Fliers E, Wiersinga W. Prevalence of Growth Hormone Deficiency in Hashimoto's Thyroiditis. J Clin Endocrinol Metab. 2010; 95(5): 2266-2270. doi: 10.1210/jc.2009-2016

16. De Bellis $\mathrm{A}$, Bizzarro $\mathrm{A}$, Conte $\mathrm{M}$, et al. Antipituitary antibodies in adults with apparently idiopathic growth hormone deficiency and in adults with autoimmune endocrine diseases. J Clin Endocrinol Metab. 2003; 88(2): 650-654. doi: 10.1210/jc.2002-021054

17. Manetti L, Lupi I, Morselli L, et al. Prevalence and functional significance of antipituitary antibodies in patients with autoimmune and non-autoimmune thyroid diseases. J Clin Endocrinol Metab. 2007; 92(6): 2176-2181. doi: 10.1210/jc.2006-2748

18. Teng $L$, Bui $H$, Bachrach $L$, et al. Catch-up growth in severe juvenile hypothyroidism: treatment with a GnRH analog. I Pediatr Endocrinol Metab. 2004; 17(3): 345-354.

19. Jaruratanasirikul $S$, Leethanaporn $K$, Khuntigij $P$, Sriplung $H$. The clinical course of Hashimoto's thryoiditis in children and adolescents: 6 years longitudinal follow-up. J Pediatr Endocrinol Metab. 2001; 14(2): 177-184.

20. Rivkees SA, Bode HH, Crawford JD. Long-term growth in juvenile acquired hypothyroidism: the failure to achieve normal adult stature. N Engl J Med. 1988; 318(10): 599-602. doi: 10.1056/NEJM198803103181003 